Acta Biologica Plantarum Agriensis 5(1): 41 (2017) ISSN 2061-6716 (Print), 2063-6725 (Online) http://abpa.ektf.hu/
DOI:10.21406/abpa.2017.5.1.41

$4^{\text {th }}$ CC 2017 Abstract

Lecture

\title{
OLIGOTROPHIC PEAT BOGS AS MACROFUNGAL REFUGES IN THE EASTERN CARPATHIANS
}

\author{
Nagygomba refúgiumok a Keleti Kárpátokban: tőzeglápok
}

\section{Ferenc PÁL-FÁM ${ }^{1}$ \& Lajos BENEDEK ${ }^{2}$}

\author{
${ }^{1}$ Kaposvár University, Institute of Plant Science; ${ }^{2}$ Szent István University, Faculty of \\ Horticultural Sciences, Department of Botany and Soroksár Botanical Garden; \\ e-mail: palfam.ferenc@ke.hu
}

Oligotrophic peat bogs are vulnerable, special habitats with unique funga, preserved only in small spots. The climatic extremities accelerate their degradation. Systematic field surveys have been made from 1998 on the macrofungi of six bogs: Mohos, Lucs, Ördög-lake, Fenyőkút, Veresvíz and Poiana Stampei in Pino-Sphagnetum magellanicii (PIN-S) and Sphagno-Piceetum (S-PIC) stands. A total number of 294 taxa were documented with 1063 occurrence data, the majority (264 taxa, 784 data) from S-PIC, a lower number (90 taxa, 279 data) from PIN-S. Constant character species from all stands were Lactarius helvus, Russula decolorans and Russula paludosa. In the S-PIC stands several widespread spruce-connected species were fructifying. Because of their high data number, Cortinarius sanguineus, Hypholoma capnoides, Lactarius lignyotus, Lactarius picinus, Leccinum vulpinum, Pholiota flammans, Russula vinosa and Tylopilus felleus can be highlighted. Some species of the surrounding beech stands can penetrate here, like Boletus reticulatus, Lactarius vellereus, Russula solaris. Beside in drier years, species indicating disturbance can also occur: Chlorophyllum rachodes, Crucibulum laeve, Inocybe geophylla. From the rare species, Albatrellus (A. confluens, A. ovinus and A. subrubescens) and Hydnellum (H. aurantiacum, H. geogenium, H. peckii, H. scrobiculatum and $H$. suaveolens) species can be mentioned, as well as Bankera violascens, Lactarius repraesentaneus, Lactarius trivialis and Mitrula paludosa. In the PIN-S stands frequent characteristic species were Amanita fulva, Cortinarius caperatus, Fomitopsis betulina, Fomitopsis pinicola, Lactarius vietus and Suillus variegatus, all fructifying in lower number in S-PIC, too. Constant character species for PIN-S were Exobasidium vaccinii, E. karstenii and Galerina paludosa. Rare species were Cortinarius chrysolitus, C. tubarius, Exobasidium juelianum, Hypholoma ericaeum, Lactarius sphagneti, Pseudoplectania sphagnophila, Russula longipes and $R$. consobrina. The functional distribution showed a mycorrhizal dominance in all stands (50-80\%), followed by the wood inhabiting saprotrophic $(10-30 \%)$. The proportion of the soil saprotrophic species was between $10-15 \%$ in the S-PIC, while the rare functions were occurring only in the PIN-S: mossconnected (Arrhenia onisca, A. sphagnicola, Bogbodia uda, Galerina gibbosa, G. paludosa, Hypholoma elongatum and Rickenella fibula); and biotrophic parasite (Exobasidium spp.). Ten species are stated in the Romanian Red List, three vulnerable (VU): Catathelasma imperiale and Craterellus lutescens from S-PIC, and Suillus flavidus from PIN-S;.seven near threatened (NT), all from S-PIC: Amanita regalis, Clitocybe odora, Gyromitra infula, Hydnellum suaveolens, Lactarius picinus, L. uvidus and Rickenella fibula. Beside Lactarius helvus, Leccinum variicolor, Porphyrellus porphyrosporus, Russula claroflava and Sarcodon scabrosus are probably endangered. 